\title{
The first disciples of Jesus in Galilee
}

\author{
Santiago Guijarro ${ }^{1}$ \\ Universidad Pontificia de Salamanca \\ Spain
}

\begin{abstract}
Early Christian writings provide little information about the Jesus movement in Galilee, but the study of the pre-Synoptic-, and especially the pre-Markan collections, can shed some light on this important period of the beginnings of Christianity. This essay starts by reconstructing the pre-Markan collection of Galilean controversies (Mk 2:1-3:6) and argues that its composition could have taken place in Galilee. These controversies reflect a process of construction of group identity whose main traits can be identified with the aid of social identity and cultural memory studies. This process can also be placed in the historical context of the emergence of sectarian groups within Second Temple Judaism. The contention of this enquiry is that the pre-Markan collection of the Galilean controversies can provide valuable information about the first disciples of Jesus in Galilee.
\end{abstract}

\section{INTRODUCTION}

The almost complete silence of both Christian and non-Christian sources regarding the Jesus movement in Galilee is a striking and intriguing fact.

Galilee was the main scenario of Jesus' activity, and it is reasonable to think that his disciples would have continued there the movement he began. How, then, are we to explain the fact that so little information has come down to us concerning these Galilean disciples? ${ }^{2}$

\footnotetext{
${ }^{1}$ Dr Santiago Guijarro is Professor of New Testament at Universidad Pontificia de Salamanca (Spain). He is a research associate of Prof Dr Ernest van Eck, Department of New Testament Studies, Faculty of Theology, University of Pretoria, in collaboration with their shared participation in the Context Group: A Project on the Bible and its Cultural Environment (USA).

${ }^{2}$ The only direct information about the presence of the disciples in Galilee consists of two announcements of Jesus' future encounter with them in the Gospel of Mark (Mk 14:28 and 16:7), two accounts of appearances of the risen Jesus (Mt 28:16-20 and Jn 21:1-23), and a general reference in the book of Acts, according to which "... the church throughout all Judea, Galilee, and Samaria enjoyed peace" (Ac 9:31). Lake (1933) defended the existence of a Galilean tradition of the appearances, but his explanation does not presuppose the existence of a Galilean Christianity because, according to him, after these appearances the disciples returned to Jerusalem.
} 


\section{The first disciples of Jesus in Galilee}

The absence of extant sources explains why scholars have tried to identify other writings that could testify to the existence of groups of disciples in Galilee. Lohmeyer (1936) saw in the tradition of the appearances and in the accounts of the Gospels a reflection of the existence of two centers of Christianity in Palestine: one in Jerusalem, and another in Galilee. Somewhat later, Elliott-Binns (1956:33-53) based his reconstruction of Galilean Christianity on the Letter of James, which, according to him, would have been written in Galilee.

In recent years other studies have appeared that seek information about these first Galilean disciples of Jesus in pre-Gospel traditions. The most circulated and best known proposal is the one which places the composition of $Q$ in Galilee, making this document the primary source for the reconstruction of the Jesus movement there before the Jewish-Roman war (Kloppenborg 2000:214-261). Others, like Schenke (1990:203-216), have tried to reconstruct the Jesus movement in Galilee from oral traditions, especially the popular miracle tradition.

In line with these recent studies, the present essay seeks to analyse the collection of the so-called "Galilean controversies" (Mk 2:1-3:6) to determine if it can be used as a source for the study of Galilean Christianity, and to find out what information they can provide about the group of disciples for whom they were composed.

\section{THE PRE-MARKAN COLLECTION OF "GALILEAN CONTROVERSIES"}

According to Theissen (1991:239-242), the author of the Gospel of Mark included in his account community traditions from Jerusalem (the account of the passion and the eschatological discourse), along with popular traditions (miracle stories) and disciple traditions (sayings and pronouncement stories) originating in Galilee. Of these three groups of tradition the most relevant for the purposes of our study is the last, because the disciple traditions are those that provide more information concerning the groups through which they were transmitted.

Particularly interesting are the disciple traditions that were gathered in small collections before being integrated into the Gospel of Mark, because the fact of being grouped together indicates that they responded to concrete problems of those who gathered them. Kuhn (1971) studied these pre-Markan collections and identified three that contain disciple traditions: a collection of controversies (Mk 2:1-3:6); a collection of parables (Mk 4:1-34); and a 
collection of community instructions (Mk 10:1-45). ${ }^{3}$ In this article the first of these three will be focused on, since it is the source that most clearly displays a disciple character and also is the source that can be reconstructed with more precision. Also, it is the source that can be located in Galilee with the highest probability.

In the Gospel of Mark, the section of the so-called "Galilean controversies" consists of five small units. Not all of them, however, are preMarkan. Kuhn includes in this collection only the first four units, arguing that in the first and in the fourth the title "Son of Man" (Mk 2:10, 28) does not have eschatological overtones as in the rest of the gospel. ${ }^{4}$ Mark likely added the last story (Mk 3:1-5) in order to give the collection the form of a perfectly balanced triptych (Dewey 1985:115-116). He also added the sentence which functions as a conclusion to this series of controversies (Mk 3:6) for the purpose of relating the initial opposition to Jesus in Galilee with the opposition he will experience in Jerusalem later in his narrative.

A closer analysis shows, however, that the first story and the last one share some characteristic traits that distinguish them from the other three. Firstly, in these two narratives the disciples do not intervene, whereas in the others they play a very important role. Secondly, the discussion is directly centered on the power of Jesus and not on his behavior or that of his disciples, as in the case of the other three stories. Thirdly, only the first and the last controversies include a miracle. To these shared traits can also be added the fact that in both stories the references to the passion are more evident than in the others: in the first one, Jesus is accused of blasphemy, as in the interrogation before the High Priest (cf Mk 2:7 and Mk 14:64), and in the last episode $\mathrm{He}$ is asked to cure on the Sabbath in order to accuse him, as $\mathrm{He}$ would later be accused before Pilate (cf Mk 3:2 and Mk 15:3-4). This agreement is especially relevant in order to determine the history of the composition of this collection of controversies, because the use of passion

\footnotetext{
${ }^{3}$ After examining previous proposals, Kuhn (1971:14-45) concludes that the author of the Gospel of Mark used these three and possibly a fourth collection of miracles (Mk 4:35-6:52). These collections contain small units drawn from the oral tradition, in order to respond to necessities in the community or group in which they were composed (Kuhn 1971:47-49). To these clusters could be added yet another of purely discipleship character, which contained traditions related to Peter in Capernaum. Although Kuhn rejects the proposal of Pesch (1968:271-274) regarding this pre-Markan composition, it ought to be taken into account when seeking to recover the Galilean traditions of Mark.

${ }^{4}$ This title is not used again in Mark until the first announcement of the passion (Mk 8:31). From that point on, it is used with relative frequency and always with an eschatological meaning, whereas in Mark 2:10 and 2:28 it refers to the power of Jesus to forgive sins and his lordship over the Sabbath (Kuhn 1971:81-89).
} 


\section{The first disciples of Jesus in Galilee}

vocabulary in Mark 1-13 reveals the evangelist's redactional activity. ${ }^{5}$ It is quite probable, therefore, that Mark included the first and the last controversies in order to create a triptych whose central piece would be the traditional collection of three controversies (Mk 2:13-28; see Gnilka 1978:131132; Marcus 2000:213-214). The location of this triptych at this precise point in his narrative and the relationship with the passion should also be attributed to the Markan redaction.

In addition to this major redactional activity three other minor interventions in the pre-existing collection can be recognized. Two of these bring "the people" onto the scene. The most recognizable is the intervention in $2: 15$, because it is introduced by an explicative "gar" in the enclitic position, which is characteristic of Mark's style: "for there were many of them who were following him." The other intervention is found in 2:13: "all the multitudes were coming to him." Both additions serve the purpose of playing down the importance of the disciples and widening the circle of Jesus' followers (Rolin 2001:122). ${ }^{6}$ A third minor redactional intervention can be found in Mark 2:22, where the saying about the wine and the wineskins is followed by the commentary "but one puts new wine into new wineskins", insisting on the theme of new wine, to which Jesus will refer again in the account of the Last Supper (Mk 14:25; see Rolin 2001:123). ${ }^{7}$

Once the redactional work done by Mark has been identified, it can be asked if the pre-Markan composition shows any indications of re-elaboration. This information would be useful for ascertaining the perspective and the intentions of the group of disciples that gathered the single stories to form this little collection.

The account of the calling of Levi that is now included in the first story (Mk 2:13-14), is an independent tradition. ${ }^{8}$ It was added to the original controversy, together with the saying about calling sinners, thus providing it

\footnotetext{
${ }^{5}$ The general conclusion added by Mark (Mk 3:6) is also a veiled announcement of the passion. The three references belong to a larger series of allusions to the passion that Mark has introduced to relate the traditions gathered in the first part of his account (Mk 1-13) with the account of the passion (Mk 14-16; see Guijarro Oporto 2006:13-20). Rolin (2001:126-127) also considers redactional the allusions to the passion in Mark 2:7b and Mark 3:6, assigning them a functional structure in the composition of the collection.
}

${ }^{6}$ The downplaying of the role of the itinerant disciples is a reflection of the distancing of Mark from them, while the widening of the circle of recipients reflects his appraisal of the local communities (see Roh 2001:145-163).

\footnotetext{
${ }^{7}$ A redactional analysis of the passion narrative shows that the words on the bread and wine (Mk 14:22-25), although being an old tradition, were introduced by Mark in the pre-Markan account (Guijarro Oporto 2007a:174). The mention of new wine could be a reference to the Markan passion narrative.

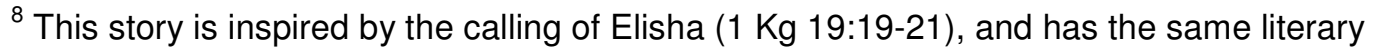
pattern as other calling accounts (Mk 1:16-18, 19-20; see Guijarro Oporto 1998:170-174).
} 
with a new framework that related Jesus' attitude towards sinners and tax collectors to his mission. ${ }^{9}$ In the second controversy two sayings of Jesus were added that originally had nothing to do with the question about fasting (Mk 2:21-22). These sayings do not show any sign of Markan redaction, and therefore should be considered part of the pre-Markan collection. ${ }^{10}$ Lastly, in the third story, the argument about the transgression of David and his men (Mk 2:25-26) originally had no relationship with the question asked by Jesus' adversaries, and therefore probably was not part of the original controversy. ${ }^{11}$ This kind of argumentation is not characteristic of Mark - and thus most probably belongs to the pre-Markan composition.

On the basis of these observations three phases can be identified in the process of the composition of the "Galilean controversies." In the first one, the three controversies were transmitted independently and had a similar form (Mk 2:16-17; 18-20; 23, 24, 27). In a second phase, these three stories were grouped together due to their formal and thematic similarities, and, more importantly, due to the fact that they responded to the same practical necessities. In the process of being grouped together they were probably amplified with secondary elements like the calling of Levi and the reference to Jesus' mission in the first controversy (Mk 2:14-15a, 17c), the sayings of commentary in the second (Mk 2:21-22), and the argument about the transgression of David in the third (Mk 2:25-26). It also would have been at this point that a common introduction was given to place them "by the seashore" (Mk 2:13), and the Christological argument in the third controversy (Mk 2:28) acquired a conclusive character. ${ }^{12}$ Finally, in a third phase, the

\footnotetext{
${ }^{9}$ POxy 1244, fol 2, col 2, has preserved a version of this controversy in which neither the calling of Levi (Mk 2:14-15) nor the last saying about the mission of Jesus (Mk 2:17b) appear: "When the scribes and Pharisees and priests saw him, they were angry that he was reclining in the midst of sinners. But when Jesus heard, he said: Those who are healthy have no need of a physician..." (tr by A Bernard, in http://www.gospels.net/transla-

tions/poxy1224translation.html). It is interesting to observe that in this version of the story the disciples do not appear at all. If the controversy preserved in POxy 1244 reflects an earlier version of the story, then the disciples could have been introduced also in a latter stage in order to identify them with the attitude of Jesus towards sinners.
}

\footnotetext{
${ }^{10}$ An additional proof for this point can be found in the Gospel of Thomas, which has preserved both the sayings (GThom 47c) and the pronouncement story (GThom 104), but in different logia and without any relationship between them.

${ }^{11}$ Although in Leviticus 24:5-9 it is said that the bread cakes were presented on the Sabbath, the act of eating them was not a transgression of the Sabbath, but rather a transgression of the law according to which only the priests could do such a thing (1 Sm 21:1-7).

${ }^{12}$ According to Kuhn (1971:73), the particle "kai," in Mark 2:18b alludes to the preceding mention of the Son of Man in Mark 2:10, and would therefore be an argument in favor of the inclusion of Mark 2:1-10 in the pre-Markan collection. The "kai," however, can also be interpreted as a resource for relating the third story with the other two, underlining the importance of the Christological argument in all of them.
} 
redactor of Mark's gospel added the first and last controversy (Mk 2:3-12 and $3: 1-5)$, thus creating a triptych characteristic of his style. It was also fitting at this point to locate the collection in Capernaum (Mk 2:1-2), in order to create a clear contrast between the negative reaction to Jesus in this stories and the positive reception of his message and his miracles in the same location (Mk 1:21-39). To this last phase also belongs the conclusion (Mk 3:6), which connects the whole composition with the passion narrative. ${ }^{13}$

According to the preceding observations, the pre-Markan collection of the Galilean controversies may be reconstructed as follows: ${ }^{14}$

The setting

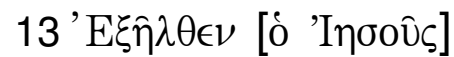
$\pi \alpha \rho \dot{\alpha} \tau \grave{\eta} \nu \theta \dot{\alpha} \lambda \alpha \sigma \sigma \alpha \nu$.

13 And he [Jesus] went out again by the seashore

The first controversy

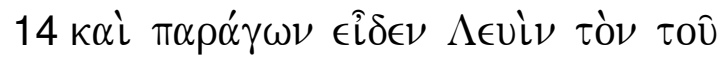
14 As he passed by, he saw Levi

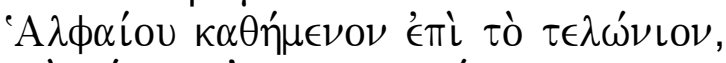

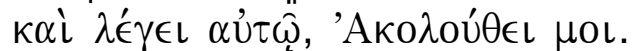

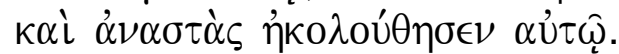

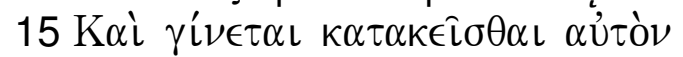

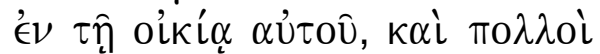

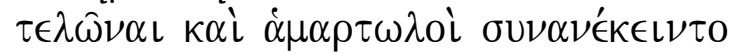

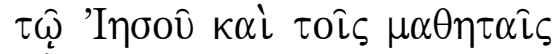

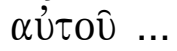

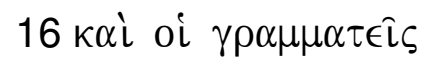

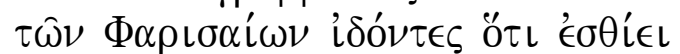

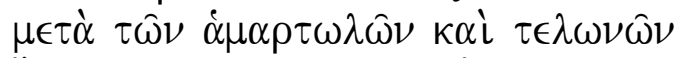

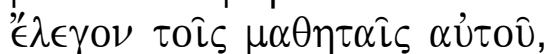

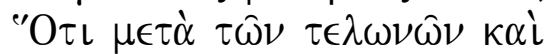
$\dot{\alpha} \mu \alpha \rho \tau \omega \lambda \hat{\omega} \nu, \epsilon \sigma \theta \dot{\epsilon} \epsilon\llcorner;$

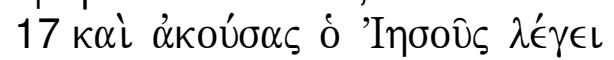

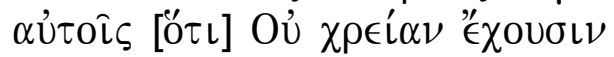

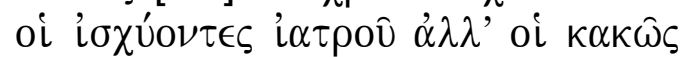

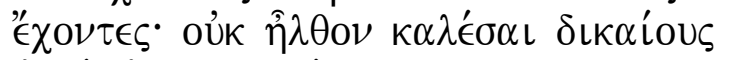
$\dot{\alpha} \lambda \lambda \dot{\alpha} \dot{\alpha} \mu \alpha \rho \tau \omega \lambda$ oús. the son of Alphaeus sitting in the tax booth, and he said to him: Follow me. And he got up and followed him. 15 And it happened that he was reclining at the table in his house, and many tax collectors and sinners were dining with Jesus and his disciples ... 16 And when the scribes of the Pharisees saw that he was eating with the sinners and tax collectors, they said to his disciples:

Why is he eating with tax collectors and sinners?

17 And hearing this, Jesus said to them: "It is not those who are healthy who need a physician, but those who are sick; I did not come to call the righteous, but sinners.

\footnotetext{
${ }^{13}$ Rolin (2001:122-125) assigns to the Markan redaction Mark 2:13-14 and 21-22, contra my argument.

${ }^{14}$ Translation from the New American Standard Bible (with slight modifications).
} 
The second controversy

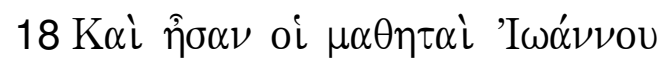

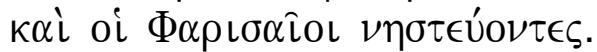

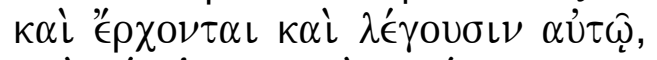
$\Delta i \dot{\alpha} \tau i ́$ oi $\mu \alpha \theta \eta \tau \alpha i$ 'I $\omega \alpha \dot{\alpha} \nu \nu 0 u$

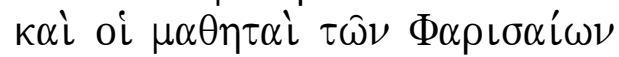
$\nu \eta \sigma \tau \epsilon u ́ o v \sigma \iota \nu$, oi $\delta ’ \epsilon$ ooi $\mu \alpha \theta \eta \tau \alpha i$ oủ $\nu \eta \sigma \tau \in \dot{O} 0 \cup \sigma \iota \nu$;

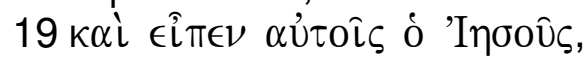
Mì $\delta u ́ \nu \alpha \nu \tau \alpha \iota$ oi vioì

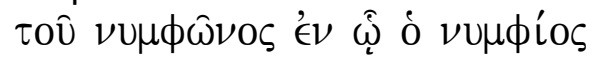

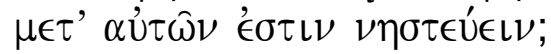

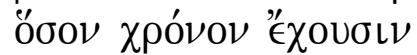

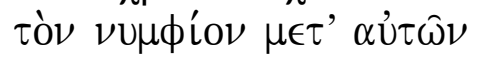

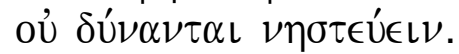

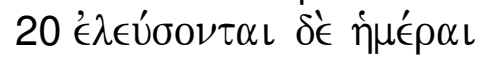

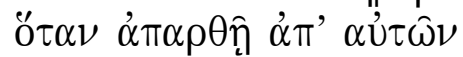

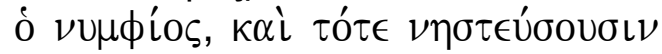

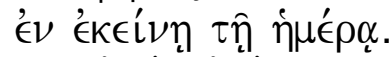

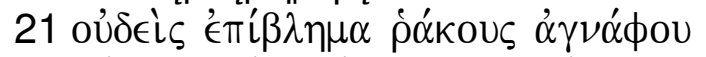

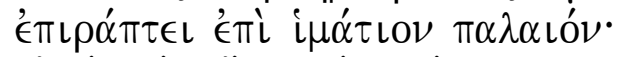

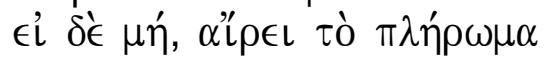

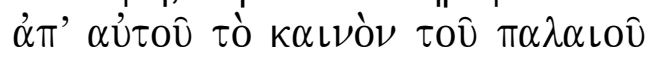

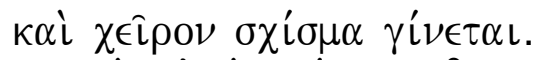

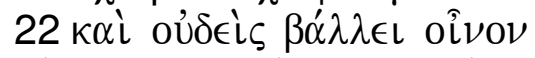

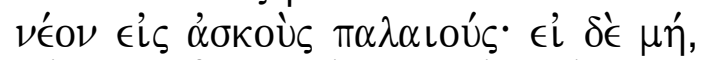

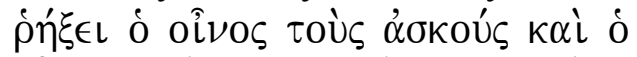

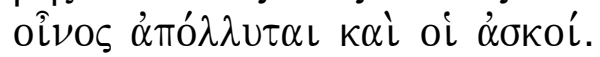

The third controversy

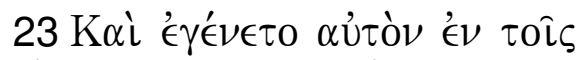
$\sigma \alpha \dot{\beta} \beta \alpha \sigma \iota \nu \pi \alpha \rho \alpha \pi о \rho \in \dot{\epsilon} \in \sigma \theta \alpha \iota$

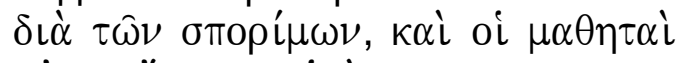

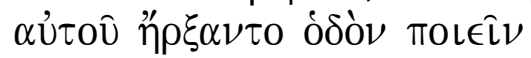

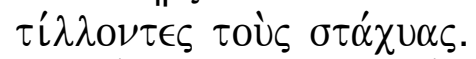

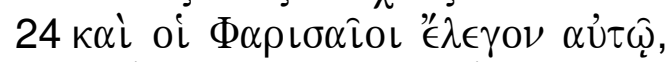

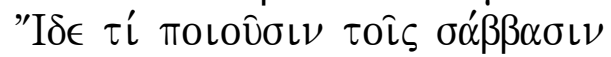
ö oủk "' $\xi \in \sigma \tau \iota \nu$;

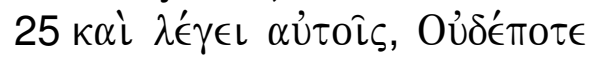

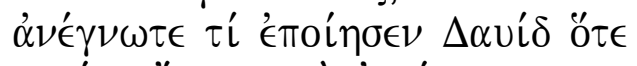

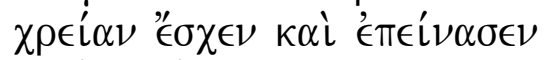

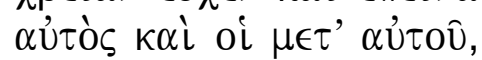

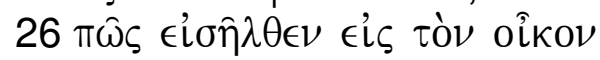

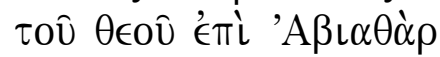

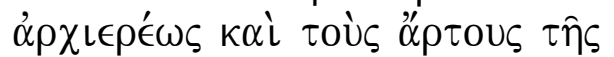

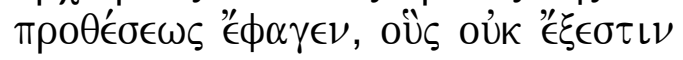

18 John's disciples and the Pharisees were fasting; and [some] came and said to him: Why do John's disciples and the disciples of the Pharisees fast, but your disciples do not fast? 19 And Jesus said to them: Can the attendants of the bridegroom fast while the bridegroom is with them? So long as they have the bridegroom with them, they cannot fast.

20 But days will come when the bridegroom is taken away from them, and then they will fast in that day. 21 No one sews a patch of unshrunk cloth on an old garment; otherwise the patch pulls away from it, the new from the old, and a worse tear results. 22 No one puts new wine into old wineskins; otherwise the wine will burst the skins, and the wine is lost and the skins as well.

23 And it happened on the Sabbath that he was passing through the grain fields, and his disciples began to make their way along while picking the heads of grain. 24 The Pharisees were saying to him: Look, why are they doing on the Sabbath what is not lawful? 25 And he said to them: "Have you never read what David did when he was in need and he and his companions became hungry; 26 how he entered the house of God in the time of Abiathar the high priest, and ate the loaves of the offering, which is not lawful for 


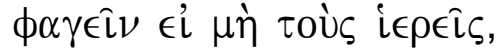

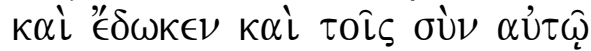
oûбเv;

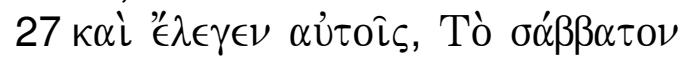

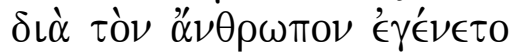

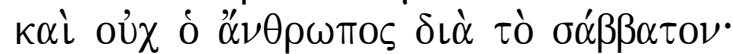

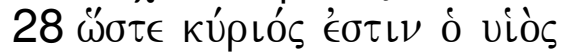

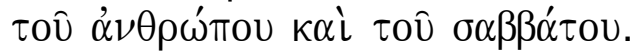

anyone to eat except the priests, and also gave to those who were with him?

27 Jesus said to them: The Sabbath was made for man, and not man for the Sabbath. 28 So the Son of Man is Lord even of the Sabbath.

Having completed the reconstruction of the pre-Markan collection our task is still not finished, because only if this reconstructed collection can be located in Galilee would it be possible to gain some relevant information about the Jesus' Galilean disciples during the first generation. To this task I now turn.

\section{THE LOCATION OF THE "GALILEAN CONTROVERSIES"}

A first clue about the original setting of the collection is found in their location "by the seashore." This way of referring to the lake of Kinnereth reflects a local perspective, since only in its immediate vicinity is the name "sea" applied to a lake (Theissen 1991:105-108). ${ }^{15}$ If Mark 2:13 was added when the preMarkan collection was formed, as I have suggested above, this location could be a clue that the collection was composed in Galilee.

This initial suggestion can be tested by examining the characters of the controversies and the topics that are discussed. The characters are, on the one hand, the "disciples of Jesus", and on the other hand, the "scribes of the Pharisees", the "disciples of John and the Pharisees", and the "Pharisees". The topics of discussion refer to some of Jesus and his disciples' behavior that their adversaries judge to be reprehensible: "eating with tax collectors and sinners," "not fasting", and "doing what is not lawful on the Sabbath." The collection of controversies could have been composed in Galilee only if the presence of the Pharisees there was significant, and if the questions of ritual purity and Sabbath observance were relevant in the region.

Concerning the presence and influence of the Pharisees in Galilee during the first century $\mathrm{CE}$, the information we have is not very conclusive. What can be deduced from the references in Josephus, the letters of Paul, and, most significantly, in the Gospels, is that there were Pharisees in Galilee. Surely they were not part of the governing class, nor did they belong to the local aristocracy, but rather "they were a minor and probably relatively new

\footnotetext{
${ }^{15}$ Other mentions of place (Mk 2:14: as he passed by; Mk 2:15: in his house, Mk 2:23: through the grain fields) are very generic. The allusion to the wine and the cultivation of cereals reflects a Mediterranean agricultural context, but nothing more.
} 
social force, struggling to influence people toward their way of life," a fact that "would explain why they were in constant conflict with Jesus and other proponents of traditional piety different from their own" (Saldarini 1988:291297, esp 295).

As for the context of Jewish observance that these controversies reflect, we can find information of great interest in the archaeological excavations of recent years. Discoveries from these excavations show that in the Roman period the cultural and religious profile of Galilee, especially in the domestic sphere, was very similar to that of Judea. ${ }^{16}$ Reed (2000:43-53) has identified four archaeological markers of Jewish identity that can be found both in Judea and in Galilee: the abundance of stone vessels, the existence of ritual baths (miqvaot), the secondary burials within ossuaries in loculi tombs, and the absence of pig bones. ${ }^{17}$ These indicators, which reveal the Jewish character of Galilee, are closely related to the topics that are discussed in the controversies between Jesus and his disciples and the Pharisees.

We have, therefore, three pieces of evidence that support the location of the pre-Markan collection of controversies in Galilee. It must be said that not all carry the same weight, but together they point to a reasonable hypothesis, which is preferable over others. The most conclusive of the evidences is the third, since it shows the relation that existed between Judea and Galilee as far as identity and religious practice were concerned. The issues raised in the controversies fit very well with the concerns of Palestinian Judaism. Taking this clue into consideration, the composition of the collection of controversies could be placed either in Judea or in Galilee. The second option, however, is much more likely, because the Christian community in Jerusalem was known for its observance of traditional Jewish practices. ${ }^{18}$

To this evidence can be added, as a last argument in favor of the Galilean location of the collection of controversies, the growing consensus about the Syrian origin of the gospel of Mark. If Mark was composed in the Syro-Palestinian region it could easily be explained why traditions from Jerusalem, such as the passion narrative, were combined with traditions from

\footnotetext{
${ }^{16}$ In the period that extends from the Assyrian conquest until the Hasmonean period the settlements in Galilee are scarce, as is the numismatic evidence. Beginning with the repopulation accomplished by the Hasmonean rulers at the end of the second century BCE, however, the settlements multiply. This datum confirms the Jewish influence in the configuration of Roman Galilee (see Reed 2000:28-43; Chancey 2005:221-229).

${ }^{17}$ For the Jewish character of Galilee and the ideology behind the Hasmonean repopulation, see Freyne (2001:289-311).

${ }^{18}$ The data in the book of Acts regarding the Jewish observance of the Jerusalem community fits well with the information given by Josephus. According to Josephus (Ant 20,199-203) the Sadducees triggered the execution of James, the brother of the Lord, who presided over the community in Jerusalem; while the "more rigorous in the observance of the law" (Pharisees?) protested against the act before Albinus (see Guijarro Oporto 2007a:194-200).
} 
Galilee, such as the collection of controversies whose reconstruction has been proposed above. ${ }^{19}$

\section{THE CONSTRUCTION OF A NEW SOCIAL IDENTITY}

The "Galilean controversies" are especially interesting for the study of the first groups of Jesus' disciples, because, unlike other stories where only Jesus intervenes, in these the disciples play an important role. What triggers the second and third controversies is a discussion on the behavior of the disciples (not fasting [Mk 2:18]; doing things unlawful on the Sabbath [Mk 2:24]), and even though in the first controversy the primary object of discussion is the behavior of Jesus (eating with tax collectors and sinners [Mk 2:16]), it is explicitly affirmed that the disciples were also seated at the table (Mk 2:15). What is discussed in these controversies, then, is not only the behavior of Jesus, but also that of his disciples. Most likely those who brought together these stories shared this kind of behavior and wanted to uphold it in front of other groups. Understood as such, the pre-Markan collection would reflect the group identity of the disciples that composed it. ${ }^{20}$

An argument in favor of this "social location" for the Galilean controversies derives from the fact that they were transmitted in an informally controlled way. This mode of transmission preserves the basic characteristics of a story while adapting it to new situations. According to Bailey (1991:4245), this kind of oral transmission is typical of those traditions that a particular group considers relevant for its identity. Unlike poems and proverbs (which were transmitted in a fixed and inflexible manner), and unlike non-relevant bits of news (which were transmitted with much freedom), the memories of persons and events that were important for the identity of a group were transmitted combining fidelity both to the tradition and to the new situation,

\footnotetext{
${ }^{19}$ Kuhn (1971:98) recognizes that location of the pre-Markan clusters depend largely on the location of Mark. According to him, the controversies can be located in Syria or even in Palestine (Kuhn 1971:98). The place of composition of Mark is a much debated issue in recent research. The location in the Syro-Palestinian region has been proposed with convincing arguments by Theissen (1991:242-249), and Marcus (1992:441-462). See also the recent proposal of Roskam (2004:75-114) who favors, with new (but not fully convincing) arguments, a Galilean setting.

${ }^{20}$ In the earlier version of the first controversy (Mk 2:16-17a) it is not expressly said that the disciples were eating with the tax collectors and sinners. As in POxy 1244 (see above note 8), the question of the scribes refers only to the behaviour of Jesus (in Mk 2:16b "eats" is in the singular). However, when this pronouncement story was expanded, the redactor included the disciples in the number of those sitting at table (Mk 2:15). This expansion of the controversy clearly reveals a change in life setting, and reveals that this memory was transmitted and preserved in order to justify later practices of open table fellowship with the authority of Jesus.
} 
and therefore with a certain degree of flexibility. ${ }^{21}$ Behind this collection of controversies there is a group that recalls events from the life of Jesus in order to strengthen its identity by confronting itself with other groups. ${ }^{22}$ In order to understand the process by which a group forms and consolidates its social identity, some basic concepts developed in the field of social psychology can be helpful. ${ }^{23}$ Social identity can be defined as "that part of an individual's self-concept which derives from his knowledge of his membership of a social group (or groups) together with the value and emotional significance attached to that membership" (Tajfel 1978:255). This general definition of social identity needs to be adapted to different cultural contexts bearing in mind that the content and relevance of this part of the individual's self concept is culturally defined. The Mediterranean culture had a pronounced collectivist orientation, and this implies that the act of belonging to a group went a long way in defining the identity of the individual (Triandis 1995:43-80). Individuals in that culture shared a dyadic understanding of personality and, therefore, understood themselves (and defined others) as part of a group, the traits of which defined much of their identity (Malina \& Neyrey 1991:72-83).

According to the preceding definition, social identity has three interrelated dimensions: a cognitive dimension by which the individual knows he or she is a member of the group, an evaluative dimension achieved by the comparison with other groups in which differences are emphasized, and an affective dimension that involves emotional attachment to the group. Only the cognitive and the evaluative dimensions will be considered here, since they can be identified more easily in the controversies.

The cognitive dimension of social identity is achieved through categorization. Categorization is one of the human mind's basic resources. It is a process by which differences are minimized and similarities are enhanced between diverse objects in order to reduce their diversity to manageable cognitive proportions. In social life this resource plays an important role in the patterning of behavior, and in the maintenance and creation of social values, norms, and beliefs that are characteristic of a group (identity descriptors). The

\footnotetext{
${ }^{21}$ According to Bailey (1991:50), the situation in the rural zones of Palestine before the Jewish-Roman war in 66-70 CE was especially apt for this type of transmission (see also Guijarro Oporto 2007a:23-24).

${ }^{22}$ Theissen (1991:115-118) raises the question of the function of the pronouncement stories and comes to the conclusion that they "define social identity ... and tend to have a socially demarcating function" (Theissen 1991:133).

${ }^{23}$ For a general presentation, see Morales Domínguez (1989:41-87; see also Tajfel 1978:254-267). Esler was the first to apply the theory of social identity to the study of ancient Christian texts - see his excellent summary of social identity theory (Esler 2003:19-39).
} 


\section{The first disciples of Jesus in Galilee}

most visible result of categorization in social life is the creation of stereotypes, that is to say, abstract representations of the categories by which a group is defined (Morales Domínguez 1989). ${ }^{24}$

The evaluative dimension of social identity is achieved through comparison. Groups become aware of their value when they compare themselves with other groups. This comparison is usually dominated by an attitude of favoritism towards the in-group, and consequently by an attitude of discrimination towards the out-group or out-groups (Domínguez 1989:59-67; Tajfel 1978:256-259). Individuals need to have a positive view of their group, because this positive view contributes to the positive perception of their own selves. In the Mediterranean society of the first century, which had a collectivist (dyadic) orientation and whose core value was honor, this evaluative dimension of social identity was achieved through public confrontation in a situation like the one presupposed in the controversies (Malina 1991:29-32, 38-41). In such a context the positive evaluation of the ingroup in its confrontation with the out-group is also highly intensified, because of the importance of group affiliations for the understanding of the individual's identity (Triandis 1995:68-72).

In addition to these synchronic aspects of social identity, there is also a diachronic dimension by which groups establish a relationship with persons and events in the past or in the future in order to define or reinforce their identity. In traditional cultures, such as the one in which Jesus and his disciples lived, this diachronic dimension was strongly oriented towards the past and was closely related to cultural memory. Cultural memory is a form of collective memory that concentrates on fixed events of the past that are relevant for the identity of a society. According to Assmann (1995), it includes "that body of re-usable texts, images and rituals specific to each society in each epoch, whose cultivation serves to stabilize and convey that society's self-image" (Assmann 1995:132). The first groups of Jesus' disciples shared with other Judean groups a cultural memory that was shaped by the epic traditions of Israel, and reference to it was a privileged means for constructing group identity.

\footnotetext{
${ }^{24}$ Morales Domínguez (1989:58) relates the cognitive aspect with the creation of stereotypes through which individuals determine the similarities which unite them and differences that distinguish them from others, and with the discrimination through which the differences between the members of these different categories are perceived. According to Tajfel (1978:115), "social stereotypes consist of assigning certain traits in common to individuals who are members of a group and also of attributing to them certain differences in common from members of other groups" (on categorization see Morales Domínguez 1989:132-134).
} 


\section{THE SOCIAL IDENTITY OF THE DISCIPLES BEHIND THE "GALILEAN CONTROVERSIES"}

The preceding observations regarding the process by which the social identity is constructed and maintained can help to explain how the group of Jesus' disciples that gathered and transmitted the Galilean controversies constructed their group identity. In the three stories the categorization of the in-group and of out-group(s) is clearly visible. In all of them there is also a tendency to create and maintain a positive identity through comparison. In the first and the third we also find references to the Israelite cultural memory. These three indicators of group identity construction will now be examined, starting with categorization.

As stated above, categorization is achieved by highlighting a few characteristics that the members of a group have in common in order to transform them into descriptors. In the case of the controversies, this process can be seen in the characterization of the groups that appear in them: Jesus' disciples as the in-group, and his adversaries as the out-group(s).

The first characteristic of the in-group that is highlighted in the controversies is the condition of being "Jesus' disciples", which all the members share (Mk 2:15, 16, 18, 23). The positive value of this group identity descriptor comes from the positive value attached to Jesus in the three controversy stories. In the first controversy he appears as a "prophet" with authority, whose invitation is sufficient to pull a tax collector away from his regular chores. He is also presented as a "physician", whose mission consists in caring for those who have some sort of ailment. The fact that both images appear together is not a coincidence, since in the Jewish tradition the model of the healer who acts as an intermediary between God and the patient was the prophet Elijah, precisely the one whose actions here are evoked. ${ }^{25}$ In the second controversy story Jesus is presented as the "bridegroom" who now is with his friends but later will be taken from them. This image also carried with it certain connotations in the Jewish tradition, especially those which represented God as the husband of Israel and the wedding feast as an expression of the time of salvation (Hs 2; Ezk 16). ${ }^{26}$ Finally, in the third controversy story, Jesus is presented as the "Son of Man", who is the "Lord of

\footnotetext{
${ }^{25}$ The calling of Levi follows the literary pattern of the calling of Elisha (1 Ki 19:19-21). Jesus performs the role in Mark that Elijah played in 1 Kings (see Guijarro Oporto 1998:170-174).

${ }^{26}$ In the original controversy the reference to Jesus as the "bridegroom" probably did not have the messianic connotations that it acquired when it was enlarged (Mk 2:19b-20), and that we find also in other passages of the Gospels (Mt 25:1-12; Jn 3:29). The expression "is taken away from them" alludes to the death of Jesus, and the expressions "the days will come" and "in that day" refers to the time of the intervention of God (see Marcus 2000:236-238; Gnilka 1978:132-134).
} 


\section{The first disciples of Jesus in Galilee}

the Sabbath". In the pre-Markan controversies this self-designation by Jesus does not evoke an eschatological figure, but rather the theology of creation: Jesus is the man par excellence to whose service the Sabbath was instituted. ${ }^{27}$ The group identity of the disciples is thus defined by the group's connection with Jesus, who is presented as someone who has authority to legitimize a new pattern of behavior.

This general description of the shared identity is illustrated by a way of acting that is distinctive of the group. In the first controversy this behavior is described as "eating with sinners and tax collectors" (Mk 2:16), in the second as "not fasting" (Mk 2:18), and in the third as "doing what is not lawful on the Sabbath," namely, eating heads of grain (Mk 2:24). These three behaviors have to do with laws that inter alia established what could be eaten, with whom it was permitted to sit at table, when one could eat or when to abstain from food.

From a social scientific point of view, meals can be described as ceremonies that, among other things, contribute to strengthening group boundaries. Eating the same foods, or eating with a certain class of persons while avoiding others, or abstaining from eating together with others who also abstain, contributes to clearly defining the contours of the group made up of those who practice such habits. Meals express, therefore, crucial aspects of the identity of a group, and of its relationship to other groups (Neyrey 1992). ${ }^{28}$ Dietary prescriptions were, in fact, a decisive element in the definition of the identity of the groups that emerged within Judaism after the Maccabaean period. All these groups used dietary rules to define and strengthen their boundaries, distinguishing between those who belonged to the group and those who did not in order to define their respective identities. ${ }^{29}$

Thus, the categorization of the group of the disciples is achieved by stressing two identity descriptors shared by those who belong to it: their connection to Jesus, and certain behaviors related to their way of eating. The second descriptor has an intense local hue that confirms the setting of the Galilean controversies in a Judean social context. Not only does it define the

\footnotetext{
${ }^{27}$ In Mark this title generally has an apocalyptic sense derived from Daniel 7, and is applied to Jesus, especially in the passion. In this passage and in Mark 2:10, however, it does not have this connotation, but instead underlines his connection with other human beings (see Marcus 2000:246).

${ }^{28}$ For more on meals as ceremonies and their function with respect to groups, see Neyrey (1992:362-368).

${ }^{29}$ For the function of food laws in the formation of new groups within Judaism, see Baumgarten (1998:127-130).
} 
identity of the group in which it was transmitted, but it also allows us to place it in a precise context: that of the flourishing of diverse groups within Judaism. ${ }^{30}$

The second resource that groups use to define their identity is comparison. Comparison requires, in the first place, a categorization of the out-group(s). It also implies a positive evaluation of the in-group. The outgroup with which the in-group of Jesus' disciples is comparing itself is basically the same in the three controversies: "the scribes of the Pharisees" (Mk 2:16); "the disciples of the Pharisees" (Mk 2:18); and "the Pharisees" (Mk $2: 24)$, even though in the second instance "the disciples of John" are also mentioned (Mk 2:18). The fact that these groups are mentioned without further explanation indicates that the original audience of the controversies was familiar with them. They were, indeed, groups that were well known in the first century Palestinian context. ${ }^{31}$

The characterization of these groups is made in an indirect way. It is presupposed that the scribes of the Pharisees would not sit at the same table with sinners and tax collectors (Mk 2:16). It is expressly stated that the Pharisees and the disciples of John practiced fasting (Mk 2:18). Implicit also is the fact that the Pharisees rigorously observed the Sabbath. Their observance of certain norms associated with food serves, here again, as a descriptor of the group's identity. For them, as was the case with other Judean groups of their day, the observance of such purity laws related to meals was an instrument for establishing boundaries and distinguishing their members from other Judeans. $^{32}$

The controversies present three different confrontations between the Pharisees and the group of Jesus' disciples, but given their thematic coherence and the centrality of the food laws in the Judaism of that day, the collection has an exemplary and representative character - the three controversy stories can therefore be considered as three examples of one and the same attitude. The confrontation takes place clearly within the framework

\footnotetext{
${ }^{30}$ This phenomenon has been studied recently by Baumgarten (1997:125-147). The results of his study are especially interesting for determining the context in which the first groups of disciples in Palestine emerged.

${ }^{31}$ For a description of the Pharisees as a group, see: Saldarini (1988:277-297). The scribes, mentioned in the first controversy, were a specialized group which had diverse affiliations (Saldarini 1988:241-276). The disciples of John are mentioned in other gospel traditions: Q 7:18; Mk 6:29; Lk 11:1; Jn 1:35, 37; 3:25; and possibly in Acts 19:3.

${ }^{32}$ Presupposing a background of common Jewish observance, Baumgarten (1988:131-139) identifies a spectrum that situates Banus and John the Baptist in the most radical extreme, the Essenes, the Qumran sect as strict observers, and the Pharisees as the most moderate observers of food laws. The Pharisees indeed carried out purification rites before meals and had precise regulations concerning which foods could be eaten and how to prepare them, but dined with non-Pharisees who would accept their rites of purification and their food.
} 


\section{The first disciples of Jesus in Galilee}

of Israelite dietary laws, which seem to be shared by all. There is no argument here as to whether or not it is lawful to practice table fellowship with nonJudeans, although the possibility that those who gathered the collection of controversies considered such a situation as unlawful, should not be discarded. At issue here are certain practices intended to differentiate sectarian groups within Judaism. ${ }^{33}$ In this framework the rebukes directed toward Jesus' disciples by their adversaries contain a critique regarding their pretension of being a group with its own identity. What Jesus' disciples do eating with sinners, not fasting, or eating improperly on the Sabbath - was what Gentiles and Hellenized Judeans did and that is the reason why the more rigorous groups wanted to differentiate themselves from them.

The answer given to these accusations in the earliest version of the controversies was based on popular wisdom and common sense: "it is not those who are healthy who need a physician, but those who are sick" (Mk $2: 18 a)$, "while the bridegroom is with them, the attendants of the bridegroom do not fast, do they?" (Mk 2:19a), "the Sabbath was made for man, and not man for the Sabbath" (Mk 2:27). These responses, which already reveal a positive evaluation of the behavior that identifies Jesus' disciples, are reinforced in the pre-Markan collection with another series of Christological arguments grounded on Jesus' mission: "I did not come to call the righteous, but sinners" (Mk 2:17b), and in his lordship over the Sabbath: "The Son of Man is Lord even of the Sabbath" (Mk 2:28). The positive evaluation of the ingroup is thus based on the person and on the authority of Jesus.

The analysis of inter-group comparison in the Galilean controversies reveals a situation in which the identity of the in-group was threatened and a positive differentiation needed to be constructed. The stress laid on food laws that served to define sectarian groups in the Palestinian society of the time reflects this strategy of differentiation, as does the marked favoritism toward the in-group achieved through the close attachment of its members to Jesus.

As described above, the third resource in the process of group identity construction is the appropriation of cultural memory. In the context of the first groups of Jesus' disciples this was achieved through reference to persons and events in the epic past of Israel. In the controversies we find one explicit reference - the story of David and his men who ate the loaves that only the priests could eat (1 Sm 21:2-7; Mk 2:25-26). The audience of the

\footnotetext{
${ }^{33}$ The term "sect" or "sectarian group" is used here in the sense that it is usually given in sociological studies. According to Baumgarten (1997:7), a sect can be defined as "a voluntary association of protest, which utilizes boundary mechanisms to distinguish between its own members and those otherwise normally regarded as belonging to the same national of religious entity."
} 
controversies, however, most probably also identified in the story of the calling of Levi a reference to the calling of Elisha by Elijah (1 Ki 19:19-21; Mk 2:14).

This allusion to Elisha's calling by Elijah, together with the reference to Jesus' mission in Mark 2:17b, were intended to present him as a prophet sent to heal those in need and to call sinners. In the cultural memory of Israel Elijah was remembered as the prophet who gathered a group of itinerant disciples and who performed miracles (1 Ki 17-2 Ki 2; Sir 48:3-5; see Öhler 1997:1-30). Both aspects appear in the first controversy, where the reference to Elijah has the effect of characterizing Jesus as a prophet with authority. Elijah also was remembered for his association with Gentiles (1 Ki 17:7-24, recalled in Lk 4:25-26), a behavior that Jesus and his disciples also display when they eat with sinners and tax collectors. Thus the implicit but evident reference to Elijah in the first controversy establishes continuity between the attitude of Jesus and his disciples towards sinners and that of Elijah towards Gentiles.

In a similar way the reference to the story of David and those with him establishes a relationship between their behavior and that of Jesus' disciples. This story, as noted above, has nothing to do with the observance of the Sabbath. Leviticus 24:5-9 prescribes that the loaves should be presented on the Sabbath, but in 1 Samuel 21:2-7 David and his men are supposed to break a cultic prescription, according to which only the priests are allowed to eat the loaves of the offerings. Recalling this story in the context of the controversy about Sabbath observance served the purpose of identifying the behavior of the disciples with that of one of the most important characters in the cultural memory of Israel.

It is worth noting that, according to the composition process of the Galilean controversies sketched above, these two references to the cultural memory of Israel most probably were added to the pronouncement stories when they were grouped together. This implies that the process of identity construction they reflect must be located in an intermediate stage between Jesus and the composition of the gospel of Mark. In other words, these references to the past reveal the existence of a group of Jesus' disciples that were struggling to construct a (new) identity within the framework of the Israelite tradition. ${ }^{34}$

\section{THE HISTORICAL SETTING}

The process of construction of a new social identity that can be observed in the pre-Markan collection of the Galilean controversies invites us to go one step farther, asking whether it is possible to identify the context and contours

\footnotetext{
${ }^{34}$ A similar process can be observed in the $\mathrm{Q}$-document, where the references to the persecuted prophets, with whom the members of the in-group identify themselves, are at the same time one of the redactional features of the document (see Guijarro 2007b).
} 


\section{The first disciples of Jesus in Galilee}

of the group of disciples that is portrayed in them. To accomplish this, three questions are addressed: What factors could have favored the appearance of this group of disciples? Who were the adversaries against whom they were defining their identity? And, finally, what was the group of those first disciples like?

Above, when the process of categorization was described (see again Section 3), the importance of the cultural context in order to rightly understand the formation of group identity was stressed. In the context of the first groups of Jesus' disciples in Galilee a factor that most probably affected its definition as a group was the flourishing of Jewish sects after the Maccabaean period. According to Baumgarten $(1997,1998)$, the roots of this phenomenon are found in an "enclave culture" that developed in the time of the Babylonian exile, and was transferred to Palestine by Nehemiah. It was initially a "national enclave" which had as its objective the differentiation of the Israelites from other peoples. The transfer of this "enclave culture" to the sectarian groups that emerged at that time was a consequence of the failure of Maccabaean policy to maintain Judean identity over against the surrounding Hellenistic culture. Many Judean groups "coped with the new situation by forming little enclaves, smaller and more secure, to replace the larger, national enclave threatened with disintegration" (Baumgarten 1998:146). ${ }^{35}$ Whatever the case, in the Second Temple-period there were diverse sectarian groups in Palestine which defined their identity by establishing differences between themselves and other Judeans.

The flourishing of Judean sects in Second Temple-Judaism is the framework in which the formation of the early groups of Jesus' disciples took place, but this contextual factor is not enough to explain them. The crucial factors that contributed to their emergence are of another kind, as their identity descriptors indicate. Their social identity was defined, primarily, by their relationship to Jesus, with whom the movement they belonged to had begun. Their origin must be sought in the public activity of Jesus in Galilee, whose memory they recalled by remembering his anecdotes and his teachings. They were aware that the death of Jesus had given way to a new

\footnotetext{
${ }^{35}$ See also Baumgarten (1998:140-147), and Baumgarten (1997:81-113), where he shows how these groups used delimitation strategies (food, clothing, etc) to distinguish themselves from other Israelites.
} 
era, but at the same time they claimed continuity with that first phase of the movement. $^{36}$

The first groups of Jesus' disciples emerged, then, in a context in which other Judean groups were reacting to the threat of disintegration and claiming the Israelite inheritance. These groups defined their identity in contrast to other already well established groups. In the Galilean controversies the Pharisees are the major opponents of the group of disciples. It is reasonable, however, to ask whether this is a reference to the Pharisees in general, or if the group mentioned is that of the Pharisees who had joined the Jesus movement. This was already suggested by Kuhn. According to Kuhn (1971:84-85), the Christological reasoning used in the controversies (Jesus' mission, the meaning of his death and his lordship as Son of Man) implies that the adversaries recognized the authority of Jesus. It is very likely that, in a stage in which the Judean groups of Jesus' disciples had not yet neatly defined their boundaries, the Pharisees that had joined the Jesus-movement continued to live as Pharisees.

As a matter of fact, there is some evidence about the existence of an influential group of Pharisees in the Jerusalem community. This group, associated with James, triggered an important conflict in the Antiochean community, due to their understanding of table fellowship. ${ }^{37}$ If the influence of this group could make it to Antioch, we can presume that their influence was much greater in Galilee, not just because of geographical proximity, but also because Galilee was very close to Jerusalem in terms of religious practice. It is, therefore, reasonable to think that the adversaries of those who wrote and transmitted the pre-Markan collection of controversies would have been not the Pharisees in general, but Christian Pharisees associated to the Jerusalem community. If this was the case, the controversies would reflect an internal

\footnotetext{
${ }^{36}$ The awareness that there was a difference between these two eras is clearly expressed in the commentary about fasting: "days will come when the bridegroom is taken away from them, and then they will fast in that day" (Mk 2:20). The vocabulary used to speak of the death of Jesus is not from Mark, and for this reason it can be assigned to the pre-Markan collection. Fiensy 1999 has argued that the Jesus movement before his death was a peasant mass movement. After his death, however, it was transformed into a discipleship movement (see Guijarro Oporto 2007a:163-167).

${ }^{37}$ Paul refers this event, which he experienced in Antioch, in his letter to the Galatians (GI $2: 11-15)$. Although Paul's reference to this event is historically more reliable than that of Acts, both sources basically agree on what they say about the Pharisees that had become disciples (Ac 11:2; 15:5). Paul tells that "those of the circumcision" belonged to the group of James and came from Jerusalem (see Núñez Regodón 2002:105-113). The closeness of the group of James to the Pharisees also appears (although indirectly) in Josephus' report on James' death (Ant 20,199-203), as well as in the pre-Markan passion narrative (see Guijarro Oporto 2007a:194-196).
} 
conflict between different groups of Jesus' disciples that were trying to define their identities in different ways.

This information is relevant for discovering what the group of those first disciples was like. First of all it can be said that it was a group that tried to construct its identity over against other more established groups. This trait, which is evident in the controversies, implies that they were not an aggregate - more or less well-defined - of individuals. They were a group in the process of defining their shared identity over and against mainstream Judean groups, and against other groups of Jesus' disciples. They were an active reform group composed, as other reform groups, mainly of individuals from the social strata of the retainers, who occupied an intermediate echelon in the social ladder. ${ }^{38}$

The identity of this group of disciples was defined by its connection to Jesus, whom they recognized as a model for their behavior, and about whom they expressed a series of convictions and beliefs. The image of Jesus that appears in the controversies implies an acknowledgement of his mission, an interpretation of the meaning of his death, and recognition of his authority. The mission of Jesus was understood against the background of the prophetic mission of Elijah, the healing prophet evoked in the first controversy (Mk $2: 17 b)$. The meaning of his death was expressed indirectly in the use of the passive form (Mk 2:20: "when the bridegroom is taken from them"), which implicitly refers to the plan of God. Finally, his authority was connected to the understanding of him as the Son of Man (Mk 2:28). The Christology of this group, which presupposes an acknowledgment of the status of Jesus as sent by God, subject to his will and clothed in his authority, is the element that defined the identity of its members.

This identity was defined also by the actions of Jesus. In the controversies this behavior expresses the position of the group regarding food laws. This behavior is especially significant because, as was mentioned above, such laws played a central role in the way contemporary Judean groups defined their identity. In contrast with other groups, which promoted a more rigid distinction with respect to Gentiles and Hellenized Judeans, this group had a more flexible attitude: they could sit at table with sinners and were not strict in the observance of fasting and of the Sabbath restrictions. The stories told in the controversies are, therefore, representative of the

\footnotetext{
${ }^{38}$ On Jewish groups in general, see Baumgarten (1997:197-199). On the Pharisees in particular, see Saldarini (1988:35-49). Miquel (2006:101-108) suggests, with convincing arguments, that the group of disciples who composed the $\mathrm{Q}$-document also belonged to the social group of the retainers.
} 
attitude of the group towards outsiders: on the one hand they clearly defined their differences with respect to other sectarian groups, and on the other hand they were open to many that would be rejected by those groups claiming that Jesus, acting as Elijah and David did, had this attitude towards those who in the eyes of the Pharisees behaved like non-Judeans.

\section{CONCLUSION}

The identification of a group of Jesus' disciples proposed in this study is based on the reconstruction, localization, and dating of the pre-Markan collection of the "Galilean controversies". This reconstruction has been achieved through a redactional analysis of the Markan text, which is a problematic and debatable procedure. Also debatable is the affirmation that this collection was composed in Galilee during the first Christian generation, and in fact none of the arguments expounded here are fully conclusive. The soundness of the case argued here resides in the confluence of the diverse literary and contextual arguments, which make plausible the localization and dating as proposed.

Also, the process of the construction of a shared identity reflected in this collection of controversies fits well in a context characterized by the flourishing of sectarian groups within Judaism. This flourishing was a typically Palestinian phenomenon, and can help in understanding the emergence of the first groups of Jesus' disciples in Judea and in Galilee. In this context, the group of disciples that appears behind the Galilean controversies could represent a concrete form of the following of Jesus in Galilee during the first generation. $^{39}$

This group was composed of followers of Jesus who after his death formed a sect (reform group) within Judaism. Some of them came from the social strata of the retainers. They had preserved the tradition of the sayings of Jesus and his pronouncement stories, because in them they found a means to define their identity as a group and to orientate their behavior. This group has similarities to that which can be detected behind the Q-document, since both in $Q$ and in the Galilean controversies the members of the group are designated as disciples (cf Mk 2:15, 16, 18, 23, and Q 6:20; Q 10:2 and $Q$ $14: 26-27)$, Jesus is presented as a prophetic figure and is given the title of

\footnotetext{
${ }^{39}$ For more on this and other groups of disciples in Palestine during the first generation (see Guijarro Oporto 2007:227-252).
} 
Son of Man, ${ }^{40}$ and he (and his disciples) are accused of eating with tax collectors and sinners and sustain a relationship with the disciples of John. ${ }^{41}$

This group of disciples was constructing its shared identity through the confrontation with other similar groups. The hypothesis presented here, therefore, is that this group was defining its identity in confrontation with other group(s) of Jesus' disciples of Pharisaic observance, whose indirect description fits well with what we know of the Jerusalem community in the time of James. As such, this hypothesis also reveals the richness and plurality of Christian beginnings in Judea and Galilee, a phenomenon that still needs to be studied in more detail.

\section{Works consulted}

Assmann, J 1995. Collective memory and cultural identity. New German Critique 65, $125-133$.

Bailey, K 1991. Informal controlled oral tradition and the Synoptic Gospels. Asia Journal of Theology 5, 34-54.

Baumgarten, A I 1997. The flourishing of Jewish sects in the Maccabaean era: An interpretation. Leiden: Brill.

Baumgarten, A I 1998. Finding oneself in a sectarian context: A sectarian's food and its implications, in Baumgarten, A I, Assmann, J \& Stroumsa, G (eds), Self, soul and body in religious experience, 125-147. Leiden: Brill.

Chancey, M A 2005. Greco-Roman culture and the Galilee of Jesus. Cambridge: Cambridge University Press.

Dewey, J 1973. The literacy structure of the controversy stories in Mark 2:1-3:6. JBL 92, 394-401.

Elliott-Binns, L E 1956. Galilean Christianity. London: SCM.

Esler, P F 2003. Conflict and identity in Romans: The social setting of Paul's letter. Minneapolis, MN: Fortress.

Fiensy, D A 1999. Leaders of mass movements and the leader of the Jesus movement. JSNT 74, 3-27.

Freyne, S 2001. The geography of restoration: Galilee: Jerusalem relations in early Jewish and Christian experience. NTS 47, 289-311.

Gnilka, J 1978. Das Evangelium nach Markus, Vol I. Neukirchen: Neukirchener Verlag.

\footnotetext{
${ }^{40}$ In Mark 2:14 the behavior of Jesus evokes Elijah, while in Q 11:29-32 Jesus is related directly to Jonah. It is interesting to observe that both Elijah and Jonah were prophets of Galilean origins. With regard to the title "Son of Man", it is found in Mark 2:28 without apocalyptic connotations, as is the case in $Q 7: 34$ (related to the accusation of eating with tax collectors and sinners); Q 9:58 (related to an invitation of following); Q 11:30 (related to the request for a sign and the figure of Jonah); and Q 12:10 (in polemic with those who speak poorly of Jesus). In Q 12:40; Q 17:24, 26, and 30, however, this same title has apocalyptic connotations.

${ }^{41}$ The accusation of eating with tax collectors and sinners is almost identical in Mark 2:16 and in Q 7:34. On the other hand, Q 7:18-22 reflects a relationship between the disciples of John and the disciples of Jesus that is very similar to the one presupposed by the second controversy (Mk 2:18-19a).
} 
Guijarro Oporto, S 1998. Fidelidades en conflicto: La ruptura con la familia por causa del discipulado y de la misión en la tradición sinóptica. Salamanca:

Universidad Pontificia.

Guijarro Oporto, S 2006. La composición del evangelio de Marcos. Salmanticensis 53, 5-33.

Guijarro Oporto, S 2007a. Jesús y sus primeros discípulos. Estella: Verbo Divino. Guijarro, S 2007b. Cultural memory and group identity in Q. BTB 47 (Forthcoming). Kloppenborg, J S 2000. Excavating Q: The history and setting of the sayings gospel. Edinburgh: T\&T Clark.

Kuhn, H 1971. Ältere Sammlunen im Markusevangelium. Göttingen: Vandenhoeck \& Ruprecht.

Lake, K 1933. The command no to leave Jerusalem and the Galilean tradition, in Foakes-Jackson, F J \& Lake, K (eds), The beginnings of Christianity, Part I: The Acts of the Apostles, Vol V: Additional notes to the commentary 7, 16. London: MacMillan.

Lohmeyer, E 1936. Galiläa und Jerusalem. Gottingen: Vandenhoeck \& Ruprecht. Malina, B 1991. Honor and shame: Pivotal values of the Mediterranean world, in Neyrey 1991:25-65.

Malina, B \& Neyrey, J H 1991. First-century personality: Dyadic not individual, in Neyrey 1991:67-96.

Marcus, J 1992. The Jewish war and the Sitz im Leben of Mark. JBL 111, 441-462.

Marcus, J 2000. Mark 1-8. A new translation with introduction and commentary. New York: Doubleday.

Miquel, E 2006. Del movimiento de Jesús al grupo de Q: Un estudio sobre la localización social de la moral, in Guijarro, S (ed), Los comienzos del Cristianismo, 93-115. Salamanca: Universidad Pontificia.

Morales Domínguez, J F 1989. Identidad social y personal, in Mayor, J \& Pinillos, J L (eds), Creencias, actitudes y valores: Tratado de psicologia general, 41-87. Madrid: Alhambra.

Neyrey, J H 1991 (ed). The social world of Luke-Acts: Models for interpretation. Massachusetts, MA: Hendrickson.

Neyrey, J H 1991. Ceremonies in Luke-Acts: The case of meals and table-fellowship, in Neyrey 1991:361-387.

Núñez Regodón, J 2002. El evangelio en Antioquia. Gál 2,15-20 entre el incidente antioqueno y la crisis gálata. Salamanca: Universidad Pontificia.

Öhler, M 1997. Elia im Neuen Testament: Untersuchungen zur Bedeutung des alttestamentlichen Propheten im frühen Christentum. Berlin: Walter de Gruyter.

Pesch, R 1968. Ein Tag vollmächtigen Wirkens Jesu in Kapharnaum (Mk 1:21-34. 35-39). Bibel und Leben 9, 114-128, 177-195, 271-274.

Reed, J L 2000. Archaeology and the Galilean Jesus: A re-examination of the evidence. Valley Forge, PA: Trinity Press International.

Roh, T 2001. Die "familia dei" in dem synoptischen Evangelien. Göttingen: Vandenhoeck \& Ruprecht.

Rolin, P 2001. Les controverses dand l'Évangile de Marc. Paris: Gabalda.

Roskam, H N 2004. The purpose of the Gospel of Mark in its historical and social context. Leiden: Brill. 
Saldarini, A J 1988. Pharisees, scribes and Sadducees in Palestinian society: A sociological approach. Grand Rapids, MI: Eerdmans.

Schenke, L 1990. Die Urgemeinde: Geschichtliche und theologische Entwicklung. Stuttgart: W Kohlhammer.

Tajfel, H 1978. Human groups and social categories: Studies in social psychology: New York: Cambridge University Press.

Theissen, G 1991. The Gospels in context: Social and political history in the Synoptic tradition. Minneapolis, MN: Augsburg Fortress.

Triandis, H C 1995. Individualism and collectivism. Oxford: Boulder. 